\title{
Archipel
}

ARCHIPEL Études interdisciplinaires sur le monde insulindien

102 | 2021

Varia

\section{In Memoriam Mona Abaza, global scholar (1959-2021)}

\section{Martin van Bruinessen}

\section{(2) OpenEdition}

1 Journals

\section{Édition électronique}

URL : https://journals.openedition.org/archipel/2604

DOI : 10.4000/archipel.2604

ISSN : 2104-3655

\section{Éditeur}

Association Archipel

\section{Édition imprimée}

Date de publication : 31 December 2021

Pagination : 3-8

ISBN : 978-2-910513-87-0

ISSN : 0044-8613

\section{Référence électronique}

Martin van Bruinessen, «In Memoriam Mona Abaza, global scholar (1959-2021) », Archipel [En ligne] 102 | 2021, mis en ligne le 15 décembre 2021, consulté le 15 décembre 2021. URL : http://

journals.openedition.org/archipel/2604; DOI : https://doi.org/10.4000/archipel.2604 


\section{In Memoriam Mona Abaza, global scholar (1959-2021)}

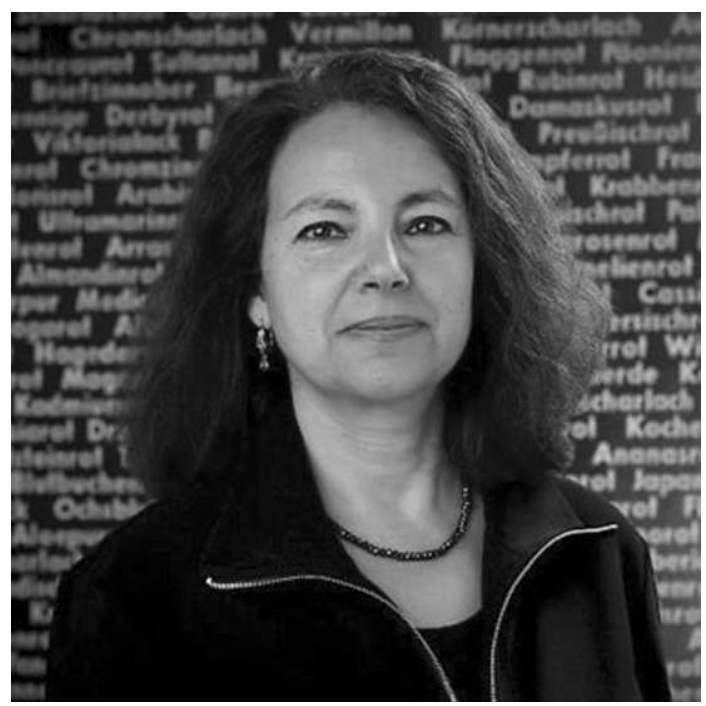

This summer the sad news reached us that the Egyptian sociologist Mona Abaza, to whom we owe insightful studies on interactions between the Middle East and Southeast Asia as well as important works on contemporary Egyptian culture and society, passed away after a long and painful struggle with cancer. Death arrived on July 5 in Berlin, where she had been receiving medical treatment, cutting short a flourishing scholarly career - even during the last months she had continued giving public lectures based on her latest book (2020), a kaleidoscopic set of vignettes of daily life in Cairo in the aftermath of the failed uprising of the Arab spring and the coup d'état by Sisi.

Mona's academic career was framed by the American University in Cairo, where she studied sociology and, after graduate studies and research fellowships in various parts of the world, returned as a lecturer in 1998 and was promoted to full professor of sociology in 2009. Several of her books 
- and this includes the most personal of her works - were published by the American University in Cairo Press, strengthening her identification with that institution, reputedly the best university in the Middle East. Her association with the city of Cairo, its social and cultural life and its cosmopolitanism, has been even stronger. In many ways she embodied Cairo and nostalgia for the city's rich and diverse cultural fabric that has gradually been declining. She moved easily in the most diverse social circles; her warm interest in marginalized groups - the Jewish and Christian minorities, the urban poor, alien residents, artists - is a recurrent theme in her work.

Some of her most impressive work, published during the past fifteen years, concerns the transformation of Cairene society during her lifetime and shows she has often been in the midst of things and a close observer of aristocratic and middle class life styles as well as street politics and vernacular expressions of political protest. There is a strong autobiographical component to these works as she kept reflecting on her own class background and positionality, most overtly so in the lavishly illustrated social and economic history of a cotton plantation in the Nile Delta, which had belonged to her maternal family (2013). The book carefully documents the decline of the landholding aristocratic class, the violent means by which members of this class sought to maintain their control over land and the peasants' vote, the changing life styles of the urban upper class as well as the peasants in the village, the brutal treatment of women of both classes, the peasants' desire for education and the growing influence of Salafis who want this education to be purely religious. It also demonstrates what made the author a remarkable sociologist: due to her family background, she had easy access to many different social circles, and her personality enabled her to establish warm relations of mutual trust with people not of her own class, such as the peasants of the former plantation, whose personal lives and choices she also documents - coming full circle, as it were, to her very first study of rural women (1987).

She had written about class relations and changing life styles before in her book on consumer cultures, in which she presented a sociology of the coffee houses and shopping malls and other venues of consumption in Cairo from the 1960s onward (2006). In one chapter, titled 'Memories,' the social and historical documentation is interwoven with personal memories of the transformation of the way of life, norms and tastes of her family and their peers: television, cars, Italian films, the first cappuccino - juxtaposed with personal observations of the changing life of the popular classes.

Mona was a close observer of the 2011 uprising at Tahrir Square and the political struggles that followed. She was especially interested in the cultural expressions of protest and struggle, on which she reported in a series of short essays in Al-Ahram Weekly and the new e-magazines Jadaliyya and Open Democracy as well as longer articles in the British journal of sociology and cultural studies, Theory, Culture \& Society. 
In spite of the centrality of Egypt, and especially Cairo, to her intellectual and emotional interests, Mona spent a large part of her academic career abroad and made Southeast Asia her other significant area of expertise. The latter interest arose naturally from her exploration of Cairo's diverse social circles and her encounter with the large community of Indonesian and Malaysian students at al-Azhar. It gave her the subject for her $\mathrm{PhD}$ thesis, which she decided to pursue at Bielefeld in Germany, where there was considerable Southeast Asia expertise. Having married the German sociologist Georg Stauth (who was also a specialist of Egyptian society), she settled for a considerable time - from 1987 to 1998 - in Germany. She obtained her PhD degree in 1990 with honours (magna cum laude), with a thesis based on extensive interviews in Cairo and Indonesia with current and former Azharis, tracing the life trajectories of the returnees and their impact on religious and political discourse in Indonesia. In the following years, she continued her interviews with Indonesian Azharis in Cairo and whenever she had occasion to visit Indonesia, resulting in a stream of publications on the subject (1991, 1993, 1994, 1996, 2003, 2010a).

Besides graduates of al-Azhar, she had also developed a network of contacts among Arabs living in Southeast Asia, most of them but not all Hadramis, and their contribution to public discourse in the lands of their residence. A two-year postdoctoral visiting fellowship at ISEAS in Singapore (1990-92) allowed her to embark upon another project on the intellectual relations between the Middle East and Southeast Asia, in which Arab scholars acted as cultural brokers. She came to know the remarkable brothers Sayyid Naquib al-Attas, the Islamic thinker, and Syed Hussein Alatas, the iconoclastic sociologist, both very well and focused on their intellectual projects. Syed Hussein had, as a graduate student in Amsterdam in the 1950s, pioneered ideas about 'Progressive Islam' and published a journal of that name, in which Mona recognized a basically secular Third-Worldism. In later writings, in the 1970 s, he developed a sociological style rooted in local knowledge and informed by postcolonial critique of Orientalism. Sayyid Naquib, a scholar of Malay Sufi literature and a vocal opponent of secularism, was then developing ideas about desecularization and the Islamization of knowledge. He had a large following among Malay students and was then at the zenith of his influence, due to the political fortunes of Anwar Ibrahim. Mona analysed these intellectual projects and the various local responses to them against the background of Malaysia's program of state-led Islamization under Mahathir and Anwar Ibrahim, of which Naquib was a major beneficiary and Hussein a vocal critic. A transnational network of Muslim intellectuals and activists played a major part in this program, which placed Malaysia temporarily in the vanguard of the world-wide Islamic resurgence. Naquib's project was endorsed by the International Institute of Islamic Thought (IIIT), an organization founded in 1981 by the Palestinian-American scholar Ismail 
Raji al-Faruqi and Anwar Ibrahim, which gained great influence in Malaysia but also had an active Egyptian branch. Mona's discovery of the Egyptian IIIT provided the occasion for more multi-sited fieldwork and comparative observations, reported in a series of articles (1998a, 1998c, 1999, 2005) and a major book (2002), which remains the major reference on the subject.

The third theme to which she devoted her attention concerned Arab perceptions of, and knowledge production about, Southeast Asia. Arab authors' lack of curiosity about the Far East is notorious, and her parsing a large amount of literature including travelogues confirmed how superficial most of this writing is $(2007 \mathrm{a}, 2011 \mathrm{a})$. She did, however, draw attention to a small number of authors who showed a more genuine interest in and knowledge of the region, notably the Egyptian Ahmad Shalaby, who had taught in Indonesia for several years. Another remarkable author she discovered was the prolific Jakarta-born Muhammad Asad Shahab, who wrote novels in Arabic that are set in Indonesia (but exclusively in Indonesian Arab circles) as well as a fiercely anti-Sukarno history of Indonesia and an account of a lengthy voyage through the southern Philippines undertaken, as he claims, on behalf of the Muslim World League (2008).

Mona Abaza established her reputation as the most prominent scholar of these three aspects of Arab-Southeast Asian relations, and she continued to pursue her interest in these themes during a string of post-doctoral appointments and fellowships, which included a half year at the Maison des Sciences de l'Homme in Paris (1994), Berlin's Free University (1994-96) and the Wissenschaftskolleg zu Berlin (1996-1997), and the International Institute for Asian Studies (IIAS) in Leiden (2001-2002). For readers of this journal it may be of interest that she established a long-lasting relationship with the Archipel group and was from 1994 to 2004 a regular contributor to its publications.

Her writing on Southeast Asia constitutes a unique body of work that has no serious competitor in international scholarship. It is a rare example of meaningful South-South relations both in the research on which it is based and in the subject matter. The work is also highly personal, as is her later writing on Egyptian society, in that it reflects the profound and lasting personal relations with the people about whom she writes, as well as her consciousness of her position as an Egyptian woman scholar of a certain class and life experience. Revisiting much of her work these last weeks, I discovered many insights that had eluded me on first reading and that once more persuaded me of the lasting relevance of her work. I am convinced that many current and future scholars of Southeast Asia will benefit from acquainting themselves with her work.

Martin van Bruinessen University of Utrecht 


\section{Selected publications by Mona Abaza}

- 1987, The Changing Image of Women in Rural Egypt [Cairo Papers in Social Science]. Cairo: The American University in Cairo.

- 1990, Cultural exchange and Muslim education: Indonesian students in Cairo. PhD thesis, University of Bielefeld.

— 1991, "Some research notes on living conditions and perceptions among Indonesian students in Cairo." Journal of Southeast Asian Studies 22, 347-360.

— 1993, "Changing images of three generations of Azharites in Indonesia." Occasional paper. Singapore: ISEAS.

- 1994, Islamic education, perceptions and exchanges: Indonesian students in Cairo. [Cahiers d'Archipel, no. 23.] Paris: Association Archipel.

— 1995, "Civil society and Islam in Egypt: the case of Nasr Hamid Abu Zayd.” Journal of Arabic, Islamic and Middle Eastern Studies 2, no.2, 29-42.

— “A profile of an Indonesian Azhari living in Cairo." Archipel 52 (1996), 31-44.

— 1997, "A mosque of Arab origin in Singapore: history, functions and networks." Archipel 53, 61-84.

— 1998a, "Debates on Islam and knowledge in two different contexts: Egypt and Malaysia." Journal of Arabic, Islamic and Middle Eastern Studies 4, no. 1, 4-17.

— 1998b, "Southeast Asia and the Middle East: Al-Manar and Islamic modernity." In From the Mediterranean to the China Sea: Miscellaneous Notes, edited by Claude Guillot, Denys Lombard and Robert Ptak, 93-111. Wiesbaden: Harrassowitz.

— 1998c, "The sociology of progressive Islam between the Middle East and Southeast Asia." In Islam - Motor or Challenge of Modernity, edited by Georg Stauth, 129-152. Hamburg: Lit.

— 1999, "Intellectuals, power and Islam in Malaysia: S.N. al-Attas or the beacon on the crest of a hill." Archipel 58, 189-217.

- 2001, "Shopping malls, consumer culture and the reshaping of public space in Egypt." Theory, Culture \& Society 18, no. 5, 97-122.

- 2002, Debates on Islam and Knowledge in Malaysia and Egypt: Shifting Worlds. London: RoutledgeCurzon.

— 2003, "Indonesian Azharites, fifteen years later." Sojourn 18, no. 1, 139-153.

— 2004, "Markets of faith: Jakartan da'wa and Islamic gentrification." Archipel 67, 173-202.

- 2005, "Syed Hussein Alatas and Progressive Islam between the Middle East and Southeast Asia." In Local and Global Social Transformation in Southeast Asia: Essays in Honour of Professor Syed Hussein Alatas, edited by Riaz Hassan, 237-60. Kuala Lumpur: Dewan Bahasa dan Pustaka.

- 2006, The Changing Consumer Cultures of Modern Egypt: Cairo's Urban Reshaping. Leiden: Brill.

- 2007a, "More on the shifting worlds of Islam. The Middle East and Southeast Asia: a troubled relationship?" The Muslim World 97, no. 3, 419-436.

— 2007b, "Shifting Landscapes of Fashion in Contemporary Egypt." Fashion Theory 11(2-3), 281-299.

— 2008, "Mohammad Asad Shahab: An Indonesian Arabic writer." In Southeast Asia and the Middle East: Islam, movement and the longue durée, edited by Eric Tagliacozzo, 250-271. Stanford CA: Stanford University Press. 
- 2010a, "The expanding and controversial role of al-Azhar in Southeast Asia." In Kindheit und Jugend in muslimischen Lebenswelten, edited by Christine Hunner-Kreisel and Sabine Andresen, 45-59. Wiesbaden: VS Verlag für Sozialwissenschaften.

— 2010b, "The trafficking with tanwir (Enlightenment)." Comparative Studies of South Asia, Africa and the Middle East 30, no. 1, 32-46.

- 2011a, "Asia imagined by the Arabs." In Islamic studies and Islamic education in contemporary Southeast Asia, edited by Kamaruzzaman Bustamam-Ahmad and Patrick Jory, 1-28. Kuala Lumpur: Yayasan Ilmuwan.

- 2011b, Twentieth Century Egyptian Art: The Private Collection of Sherwet Shafei. Cairo: The American University in Cairo Press.

- 2013a, The Cotton Plantation Remembered: An Egyptian Family Story. Cairo: American University in Cairo Press.

— 2013b, "Walls, segregating downtown Cairo and the Mohammed Mahmud street graffiti." Theory, Culture and Society 30, no. 1, 122-139.

— 2014a, "Post January revolution Cairo: Urban wars and the reshaping of public space." Theory, Culture and Society 31, no. 7/8, 163-183.

— 2014b, "Gender representation in graffiti post-25 January.” In Cairo: Images of Transition, edited by Mikala Hyldig Dal, 126-133. Bielefeld: Transcript-Verlag.

— 2016a, "Violence, dramaturgical repertoires and neoliberal imaginaries in Cairo." Theory, Culture \& Society 33, no. 7-8, 111-135.

- 2016b, "The field of graffiti and street art in post-January 2011 Egypt." In Routledge Handbook of Graffiti and Street Art, pp. 358-373. New York, etc.: Routledge.

- 2020, Cairo Collages. Everyday Life Practices After the Event. Manchester: Manchester University Press.

Mona Abaza's columns and essays in Al-Ahram Weekly, Jadaliyya and Open Democracy can be accessed at:

https://english.ahram.org.eg/WriterArticles/Mona-Abaza/386/0.aspx,

https://www.jadaliyya.com/Author/2867,

https://www.opendemocracy.net/en/author/mona-abaza/. 